\title{
Outcome of children and adolescents with lymphoblastic lymphoma
} \author{
Lúcia Porto Castro 5 , Marcos Borato Viana ${ }^{6}$

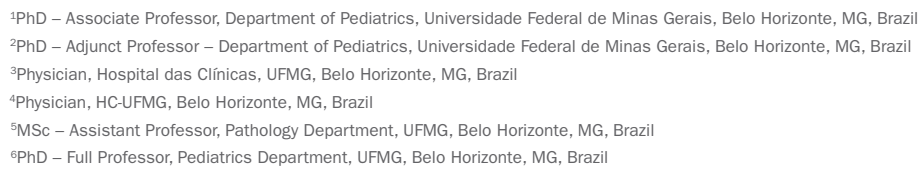

Maria Christina Lopes Araújo Oliveira ${ }^{1 *}$, Keyla Christy Sampaio ${ }^{2}$, Aline Carneiro Oliveira ${ }^{3}$, Aieska Dantas Santos ${ }^{4}$,

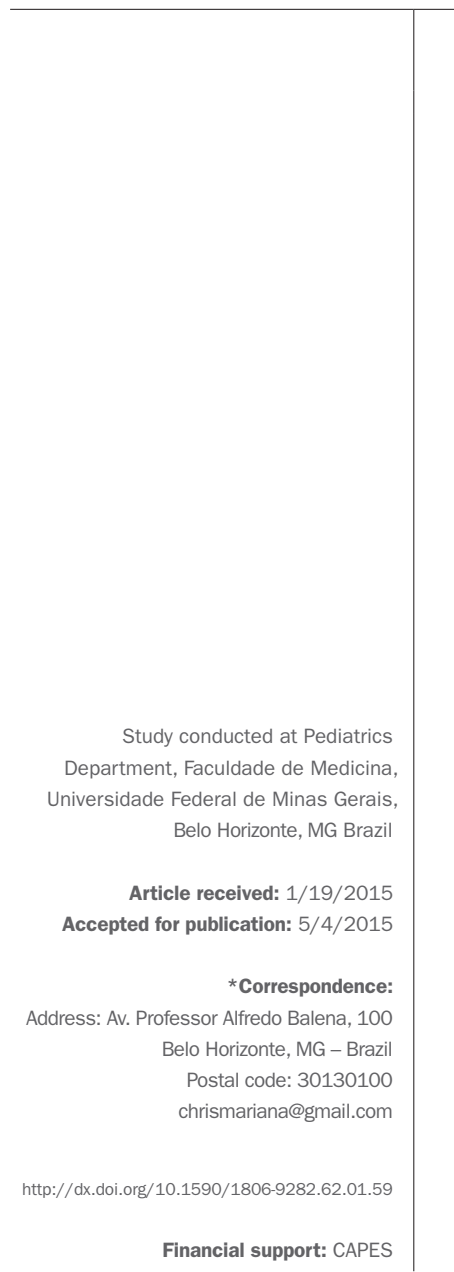

\section{SUMmarY}

Introduction: lymphoblastic lymphoma (LBL) is the second most common subtype of non-Hodgkin lymphoma in children. The aim of this study was to characterize the clinical course of children and adolescents with LBL treated at a tertiary center.

Methods: this is a retrospective cohort study of 27 patients aged 16 years or less with LBL admitted between January 1981 and December 2013. Patients received intensive chemotherapy regimen derived from acute lymphoblastic leukemia (ALL) therapy. Diagnosis was based on biopsy of tumor and/or cytological examination of pleural effusions. The overall survival was analyzed using the Kaplan-Meier method.

Results: the median age at diagnosis was 11.6 years (interquartile range, 4.613.8). LBL had $\mathrm{T}$ cell origin in 16 patients (59\%). The most common primary manifestation in T-cell LBL was mediastinum involvement in 9 patients (56\%). Intra-abdominal tumor was the major site of involvement in patients with $\mathrm{pB}$ LBL. Most patients had advanced disease (18 patients - 67\%) at diagnosis. Twenty-four patients (89\%) achieved complete clinical remission. After a median follow-up of 43 months (interquartile range, 6.4-95), 22 patients (81\%) were alive in first complete remission. Five children (18.5\%) died, three of them soon after admission and two after relapsing. The probability of survival at five years for 20 patients with de novo LBL was 78\% (SD 9.4).

Conclusion: our findings confirm the favorable prognosis of children with LBL with an intensive chemotherapy regimen derived from ALL therapy.

Keywords: precursor cell lymphoblastic leukemia-lymphoma, lymphoma, non-Hodgkin, pediatrics, survival.

\section{INTRODUCTION}

Lymphoblastic lymphomas (LBL) are lymphoid malignancies from immature or precursor cells representing one third of the cases of non-Hodgkin lymphoma (NHL) in children and adolescents. ${ }^{1-3}$ The current World Health Organization (WHO) classification assigns tumours of hematopoietic and lymphoid tissues in Tlymphoblastic leukemia/lymphoma and B lymphoblastic leukemia/ lymphoma. ${ }^{4,5}$ Of note, only approximately $10 \%$ of LBL express B-cell markers in contrast to approximately $85 \%$ of acute lymphoblastic leukemia (ALL). ${ }^{6}$ The distinction between leukemia and lymphoma is arbitrary and based on the extent of involvement of bone marrow (BM). It is usual to diagnose patients with $\geq 25 \%$ lymphoblasts in $\mathrm{BM}$ as having ALL, whereas patients with extra-medullary disease and less than $25 \%$ blasts in $\mathrm{BM}$ are diagnosed as LBL.,

Clinical presentation varies according to immunophenotype. T-cell lymphoblastic lymphomas (T-LBL) most commonly involve the anterior mediastinum and supradiaphragmatic lymph nodes. ${ }^{2,9}$ Pre-B lymphoblastic lym- 
phomas (pB-LBL) are usually localized in peripheral lymph nodes and extranodal sites, such as skin, soft tissues, and bone, with a preference for the head and neck regions. ${ }^{10,11}$

Whether LBL and ALL in childhood are biologically identical or rather distinct disorders is not entirely clear. ${ }^{12,13}$ To date, the pathogenesis and genetic changes of LBL is poorly understood. ${ }^{3}$ LBLs are most effectively treated using ALL-based therapies. ${ }^{14}$ Nowadays, event-free survival (EFS) can be reached by $75-90 \%$ of children and adolescents. ${ }^{3,15,16}$

The objective of this study was to contribute to the knowledge of the clinical course and treatment outcome of 27 children and adolescents with LBL followed up at a single tertiary center.

\section{Methods}

This is a longitudinal retrospective observational cohort study that evaluated 27 children and adolescents aged 16 years or less with LBL. The patients were admitted to the Pediatric Hematology Unit, University Hospital, Universidade Federal de Minas Gerais (UFMG), between January 1981 and December 2013. Seven patients were excluded from the Kaplan-Meier survival analysis (see statistical session) because of previous treatment at other institutions $(n=3$ ), severe concomitant immunodeficiency (one with primary and two with secondary immunodeficien$c y)$, and one with bone marrow involvement with atypical cells that were not considered lymphoblasts.

Medical records were reviewed to collect demographic data (age, gender), clinical data (medical history, physical examination, clinical presentation), diagnostic procedures (imaging studies, bone marrow aspiration, cerebrospinal fluid [CSF] analysis), staging, laboratory data (lactate dehydrogenase [LDH] levels, blood counts, serum electrolytes, liver and kidney tests), treatment, and outcome. Diagnosis was made by incisional or excisional biopsy, or cytological examination of pleural or abdominal effusions. Karyotype studies were not available at the time. All the diagnoses were confirmed by morphological and immunohistochemistry criteria defined by the World Health Organization (WHO) classification. ${ }^{17}$ Immunohistochemistry was performed using monoclonal antibodies CD20, CD10, CD79a, CD30, CD3, CD15, TdT, CD45, and CD45RO for the detection of $\mathrm{B}$ and $\mathrm{T}$ cells. Cell lineage assignment required $50 \%$ or more of positive neoplastic B or T cells. Pleural or abdominal effusions were examined by flow cytometry.

Clinical staging was based on the St. Jude Children's Research Hospital staging system. ${ }^{18}$ Central nervous system (CNS) disease was diagnosed by the presence of morphologically identifiable lymphoma cells (regardless of quantity) in CSF, an intracranial mass or cranial nerve palsy not caused by an extradural mass.

\section{Treatment}

Patients with LBL were treated according to protocols based on an ALL-type strategy. Patients admitted between 1981 and 1987 were treated according to the modified LSA2L2 protocol of the Memorial Sloan-Kettering Cancer Center. ${ }^{19}$ After 1987, patients were treated with a BFM83-based protocol (Berlin-Frankfurt-Münster). ${ }^{20}$

\section{Response criteria}

Complete remission (CR) was defined as the disappearance of all tumor masses confirmed by clinical examination and imaging investigations, one month after therapy. After the end of treatment, the patients were followed at 30-day intervals during the first year, at 60-day intervals during the second year and at 3-to 6-month intervals up to five years. Progression of the local tumor was defined if the tumor site showed no decrease in size after starting chemotherapy. Relapse was defined as the recurrence of lymphoma with the same histological or immunophenotypic features as the initial one at any site after CR was achieved. Local relapse was diagnosed when it involved a previously involved site (except bone marrow and CSF).

\section{Statistical analysis}

The time limit for the current study was the end of December 2013. Data are reported as medians and interquartile range (IQ) or means and standard deviation (SD), when appropriate. Mann-Whitney or Kruskal-Wallis tests were used to compare nonparametric continuous variables. Dichotomous variables were compared using two-tailed chisquare test or Fisher exact test. Overall survival (OS) was defined as the time from diagnosis to date of death due to any cause or date of last follow-up contact for patients who were alive. The OS was analyzed using the KaplanMeier method for 20 patients, as mentioned before.

\section{Ethical issues}

The study was approved by the Research Ethics Committee of UFMG. Written informed consent was obtained from the guardians of the patients and, when appropriate, from the patients themselves, according to the Helsinki Declaration.

\section{ResULTS}

Patient characteristics

The median age at diagnosis was 11.6 years (interquartile: 4.6-13.8 years). It was 6.1 years for patients with $\mathrm{pB}$ - 
LBL and 13.2 for those with T-LBL. There was a predominance of males (1.6:1). Diagnosis was based on cytological examination of pleural effusions in two patients (7\%), and on tumor biopsies for the remaining cases. Immunohistochemistry was performed in 21 patients and immunophenotyping in two patients. Immunohistochemistry was inconclusive in six patients due to technical problems with the fixing of samples. The clinical and demographic characteristics of the patients are shown in Table 1. LBLs were of T-precursor cell origin in the majority of cases (16 patients- 59\%). The most common manifestation at diagnosis in T-cell cases was mediastinal enlargement, observed in nine patients, followed by lymph nodes in six. Intra-abdominal tumor was the major site of involvement in patients with $\mathrm{pB}-\mathrm{LBL}$, observed in three cases followed nodal disease in two cases. A paravertebral tumor was the initial manifestation in one patient who had a secondary immunodeficiency. Most patients had advanced disease (67\%). Serum LDH concentration immediately at diagnosis was available only in 16 cases and the mean concentration was 831.63 IU/L (range: 152 to 3,897 IU/L). Serum uric acid was available for 22 patients with a mean value of $4.3 \mathrm{mg} / \mathrm{dL}$ (range: 2.0 to $8.5 \mathrm{mg} / \mathrm{dL}$ ).

\section{TABLE 1 Baseline clinical characteristics of 27 children} with lymphoblastic lymphoma.

\begin{tabular}{ll} 
Features & $\mathbf{n}(\%)$ \\
\hline Median age diagnosis (years) & 11.6 \\
\hline Pre-B LBL patients & 6.1 \\
\hline T-LBL patients & 13.2 \\
\hline Gender & $18(67)$ \\
\hline Male & $9(33)$ \\
\hline Female & \\
\hline Clinical presentation (site) & $11(41)$ \\
\hline Mediastinum & $9(33)$ \\
\hline Lymph nodes & $6(22)$ \\
\hline Abdomen & $1(4)$ \\
\hline Other sites & \\
\hline Clinical stages & $8(30)$ \\
\hline Localized disease & $18(67)$ \\
\hline Disseminated disease & $1(3)$ \\
\hline Undetermined & $5(18)$ \\
\hline Immunophenotyping & \\
\hline T lineage & \\
\hline B lineage & \\
\hline Unclassified & \\
\hline & \\
\hline
\end{tabular}

TABLE 1 (Cont.) Baseline clinical characteristics of 27 children with lymphoblastic lymphoma.

\begin{tabular}{ll} 
Features & $\mathbf{n}(\%)$ \\
\hline Characteristics & \\
\hline De novo LBL & $24(89)$ \\
\hline Primary immunodeficiency & $1(4)$ \\
\hline Secondary immunodeficiency & $2(7)$ \\
\hline Outcome & \\
\hline Death before remission & $3(11)$ \\
\hline Death after relapse & $2(7)$ \\
\hline Alive in first remission & $22(81.5)$ \\
\hline
\end{tabular}

\section{Outcome}

24 patients (9\%) reached complete remission. After a median follow-up of 43 months (interquartile range, 6.4-95), 22 patients $(81 \%)$ were alive in first CR. Five children $(18.5 \%)$ died, three of them soon after admission and two (7\%) after relapsing. Among the patients with immunodeficiency, one died and the other two are alive in first remission. The probability of survival at five years for 20 patients with de novo LBL and similarly treated was $78 \%$ (SD 9.4) (Figure 1).

\section{Discussion}

LBLs comprise approximately $30 \%$ of the NHLs that occur in children and young adults. The vast majority of them arise from immature T-cells, corresponding to defined stages of thymocyte differentiation, and approximately 10 to $15 \%$ are precursor B-cell lymphomas. ${ }^{2,15,21}$ LBL accounted for $23 \%$ of cases of NHL enrolled in our institution in the period of 26 years. Burkitt's lymphoma is the leading subtype in our institution. ${ }^{22}$

In agreement with the literature, the most frequent phenotype among our patients had T-cell origin. Approximately $20 \%$ were of $\mathrm{pB}$-cell origin, and the remaining cases were unclassified. In a Brazilian epidemiologic study, LBL represented $36 \%$ of all NHLs (272 cases). T-cell phenotype was the most prevalent representing $60 \%$ of cases; $25 \%$ were of the $\mathrm{pB}$-cell phenotype, and the remaining $15 \%$ were unclassified. ${ }^{23}$

Patients with pB-LBL were younger than those with T-LBL, as reported by others $(15,24)$. However, the median age at diagnosis for our patients with T-LBL was a little higher than reported before (around 8.8 years old). ${ }^{24}$ As also reported in previous studies, there was a clear predominance of males $(2: 1)$.

Presenting clinical features for T-LBL are quite distinct from those for $\mathrm{pB}$ - LBL. Mediastinal, bone marrow $(\mathrm{BM})$ and central nervous system (CNS) involvements are 


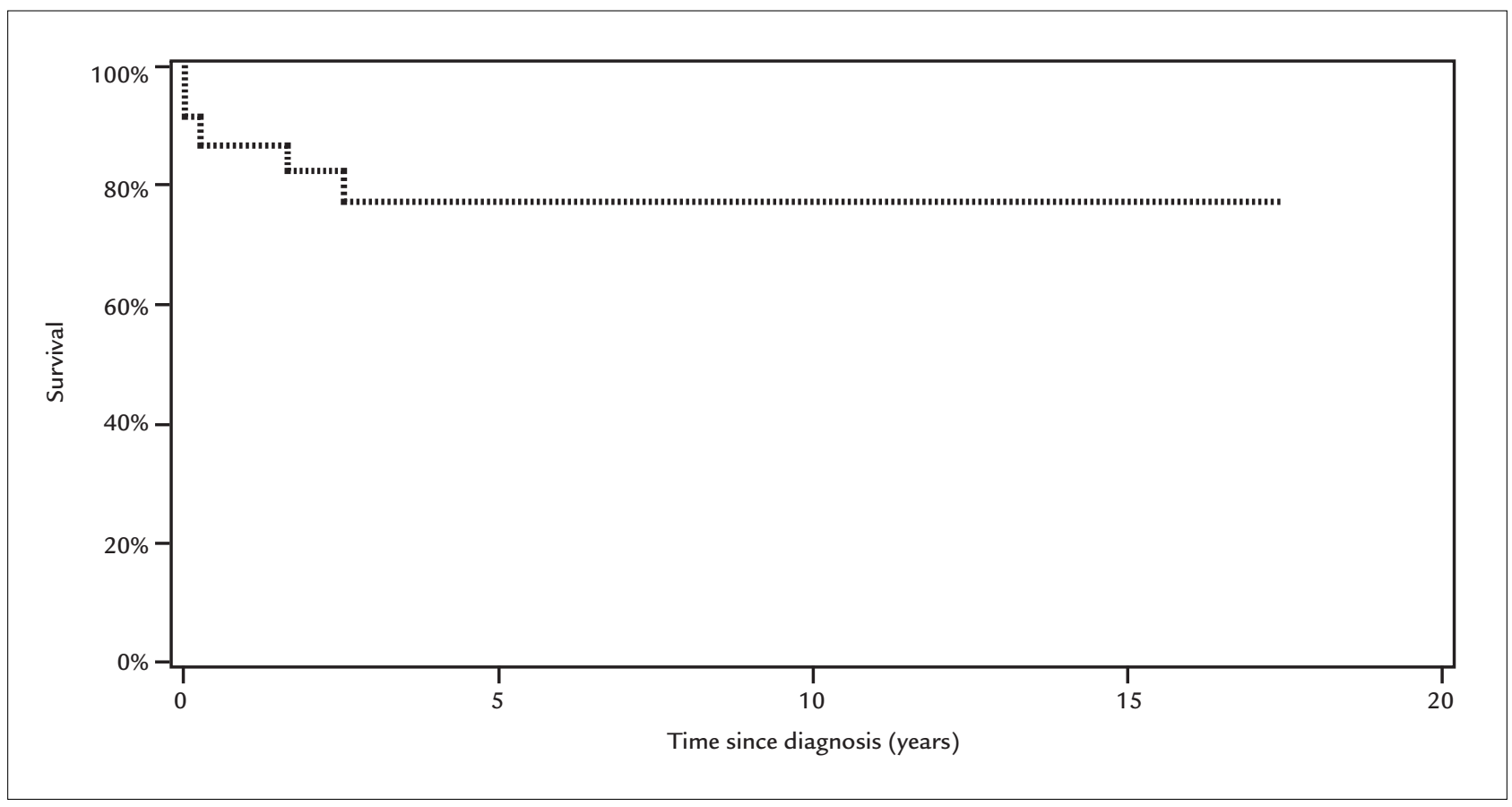

FIGURE 1 Overall survival of 20 patients with lymphoblastic lymphoma.

predominant in T-LBL. ${ }^{25}$ In the present study, mediastinal enlargement was present in more than half of the cases. Two patients had BM invasion, but CNS disease was not observed. The clinical presentation of children with $\mathrm{pB}-\mathrm{LBL}$ varies considerably. Bone, soft tissue, and visceral organs can all be involved. In a series of twenty-seven patients with $\mathrm{pB}-\mathrm{LBL}$, the majority of them had nodal disease. ${ }^{15}$ In the present study, although there were only six patients, five had intra-abdominal or lymph nodal disease as the presenting clinical manifestation.

T-LBL stage is often advanced at diagnosis (stage III-IV), unlike $\mathrm{pB}$-cell LBL, which primarily is a localized disease. ${ }^{26,27}$ These results are coincident with those observed in our series. The majority of patients were diagnosed with advanced stages of disease.

Prognostic markers in LBL are yet to be clearly defined. Age, gender, response to treatment, stage, molecular prognostic markers, and marrow and CNS involvement remain unclear as prognostic factors in LBL. For instance, in a series of 85 children and adolescents with advanced LBL the multivariate analysis failed to demonstrate age, gender, lactate dehydrogenase level, and marrow or central nervous system disease to have independent prognostic value. ${ }^{28}$ In a recent study by Burkhardt, adolescent females with T-LBL had a worse outcome. The worst outcome of girls compared with boys observed only in patients older than 9 years arose the issue whether the advanced pubertal changes of girls com- pared with boys might have contributed to worst treatment results for females with increasing age. ${ }^{24}$

In general, the outcome is worst for CNS-positive as compared with CNS-negative patients, although not for all NHL subgroups. CNS involvement occurs more frequently in patients with advanced disease. In contrast to patients with Burkitt's lymphoma, CNS involvement does not negatively impact treatment results for LBL patients. ${ }^{29}$

Over $80 \%$ of patients with T-LBL do not have marrow involvement at diagnosis by morphologic examination of bilateral marrow aspirates and biopsies. ${ }^{2}$ However, in a series of 99 children with T-LBL, more than two thirds of them had neoplastic lymphoblasts detected by flow cytometry. This finding implies that a more sensitive method for investigating neoplastic cells in the BM at diagnosis may contribute to a more appropriate risk classification. ${ }^{30}$ Persistent minimal disease during and/or at the end of induction therapy may also identify a poor risk group of patients. ${ }^{30}$

In relation to stage, patients with localized disease have a good prognosis. ${ }^{31}$ Disease stage was a major prognostic factor for children with pB-LBL, with significant better overall survival and event-free survival rates observed in patients with stage I to III as compared to those with stage IV. ${ }^{21}$ In the present study, out of five patients who died, four had disseminated disease. The fifth patient had localized disease and primary immunodeficiency. 
No single recurrent chromosome abnormality has been identified as characteristic of LBL. ${ }^{31}$ Recently, activating NOTCH1 mutations (chromosome 9) were reported to be associated with favorable prognosis. Loss of heterozygosity at chromosome $6 \mathrm{q}(\mathrm{LOH} 6 \mathrm{q})$ was reported to be associated with increased relapse risk for patients with T-LBL. ${ }^{26}$

Response to treatment has been considered an important prognostic factor. In a series of 121 children with T-LBL, the ones who had reached CR on the seventh day of chemotherapy (prephase) had a better prognosis than those who had not reached CR. ${ }^{9}$

Because of its biological relationship to ALL, patients with LBL have been treated with therapeutic protocols used for ALL, which are based on the principle of continual exposure to cytostatics over a long period of time. ${ }^{32}$ Among our patients this strategy also proved highly efficacious. Only two patients relapsed (7.4\%), and both died. As reported in modern treatment protocols for LBL, 10\% of patients with progressive disease or relapse have indeed an extremely poor prognosis. ${ }^{1}$ The probability of 5-year survival for 20 patients with de novo LBL and similarly treated was almost $80 \%$, similar to those achieved in major treatment centers ( 75 to $90 \%$ ). ${ }^{3}$

\section{Conclusion}

Our findings confirm a favorable prognosis for children with LBL treated with ALL-based therapies. The subtle differences between LBL and ALL are elusive, and have raised questions as to whether identical therapeutic approaches are warranted for each immunophenotypic category. Prognostic markers in LBL have also yet to be clearly defined. The outcome for patients with recurrent disease is poor. Molecular and cellular pathogenesis of malignant transformation to LBL is still a challenge to be tackled in order to develop strategies for prevention, early identification, and targeted therapies.

\section{Acknowledgments}

This study was supported by CAPES. Dr. M. C. Oliveira received a research grant from CAPES (2767-15-5).

\section{Resumo}

Evolução de crianças e adolescentes com linfoma linfoblástico

Objetivos: linfoma linfoblástico (LL) é o segundo subtipo mais comum de linfoma não Hodgkin em crianças. $\mathrm{O}$ objetivo deste estudo foi caracterizar a evolução clínica de crianças e adolescentes com LL em um centro terciário.
Métodos: estudo de coorte retrospectivo de 27 pacientes com idade de até 16 anos com LL admitidos entre janeiro de 1981 e dezembro de 2013. Os pacientes foram tratados de acordo com o protocolo de tratamento para leucemia linfoblástica aguda (LLA). O diagnóstico foi baseado em biópsia do tumor e/ou no exame citológico de derrame pleural. A sobrevida global foi analisada pelo método de Kaplan-Meier.

Resultados: a média de idade ao diagnóstico foi de 11,6 anos (variação interquartil, 4,6-13,8). LL de células T foi identificado em 16 pacientes (59\%) e a manifestação primária mais comum foi o acometimento mediastinal em 9 pacientes (56\%). Tumor intra-abdominal foi a manifestação clínica principal nos pacientes com LL de células pré-B. A maioria dos pacientes apresentava doença avançada (18 pacientes - 67\%) ao diagnóstico. Vinte e quatro pacientes (89\%) alcançaram remissão clínica completa. Após um período de acompanhamento médio de 43 meses (intervalo interquartil, 6,4-95), 22 pacientes (81\%) continuam vivos em primeira remissão clínica completa. Cinco crianças $(18,5 \%)$ morreram, três delas logo após a admissão e duas após recidiva. A probabilidade de sobrevida em cinco anos para 20 pacientes com LL de novo foi de $78 \%$ (SD 9.4).

Conclusão: nossos resultados confirmam o prognóstico favorável de crianças com LL tratadas com regime de quimioterapia intensiva derivado da terapia de LLA.

Palavras-chave: leucemia-linfoma linfoblástico de células $\mathrm{T}$ precursoras, leucemia-linfoma linfoblástico de células precursoras B, linfoma não Hodgkin, pediatria, sobrevida.

\section{RefEREnCES}

1. Burkhardt B, Reiter A, Landmann E, Lang P, Lassay L, Dickerhoff R, et al Poor outcome for children and adolescents with progressive disease or relapse of lymphoblastic lymphoma: a report from the Berlin-FrankfurtMuenster Group. J Clin Oncol. 2009; 27(20):3363-9.

2. Cairo MS, Raetz E, Lim MS, Davenport V, Perkins SL. Childhood and adolescent non-Hodgkin lymphoma: new insights in biology and critical challenges for the future. Pediatr Blood Cancer. 2005; 45(6):753-69.

3. Schmidt E, Burkhardt B. Lymphoblastic lymphoma in childhood and adolescence. Pediatr Hematol Oncol. 2013; 30(6):484-508.

4. Borowitz MJ, Chan J. B lymphoblastic leukaemia/lymphoma, not otherwise specified. In: Swerdlow SH, Campo E, Harris NL (eds.). WHO classification of tumours of haematopoietic and lymphoid tissues. Lyon: WHO, 2008. p.168-70

5. Borowitz MJ, Chan JK. T lymphoblastic leukaemia/lymphoma. In: Swerdlow SH, Campo E, Harris NL (eds.). WHO classification of tumors of haematopoietic and lymphoid tissues. Lyon: WHO, 2008. p.176-8.

6. Maitra A, McKenna RW, Weinberg AG, Schneider NR, Kroft SH. Precursor B-cell lymphoblastic lymphoma. A study of nine cases lacking blood and bone marrow involvement and review of the literature. Am J Clin Pathol 2001; 115(6):868-75.

7. Reiter A, Schrappe M, Parwaresch R, Henze G, Muller-Weihrich S, Sauter S et al. Non-Hodgkin's lymphomas of childhood and adolescence: results of a treatment stratified for biologic subtypes and stage--a report of the BerlinFrankfurt-Munster Group. J Clin Oncol. 1995; 13(2):359-72. 
8. Reiter A, Tiemann M, Ludwig WD, Wacker HH, Yakisan E, Schrappe M, et al [NHL-BFM 90 therapy study in treatment of malignant non-Hodgkin's lymphomas in children and adolescents. Part 1: Classification and allocation to strategic therapy groups. BIF study group]. Klin Padiatr. 1994; 206(4):222-33.

9. Uyttebroeck A, Suciu S, Laureys G, Robert A, Pacquement H, Ferster A, et al. Treatment of childhood T-cell lymphoblastic lymphoma according to the strategy for acute lymphoblastic leukaemia, without radiotherapy: long term results of the EORTC CLG 58881 trial. Eur J Cancer. 2008; 44(6):840-6.

10. Muljono A, Graf NS, Arbuckle S. Primary cutaneous lymphoblastic lymphoma in children: series of eight cases with review of the literature. Pathology. 2009; 41(3):223-8

11. Ozdemirli M, Fanburg-Smith JC, Hartmann DP, Shad AT, Lage JM, Magrath IT, et al. Precursor B-lymphoblastic lymphoma presenting as a solitary bone tumor and mimicking Ewing's sarcoma: a report of four cases and review of the literature. Am J Surg Pathol. 1998; 22(7):795-804.

12. Burkhardt B. Paediatric lymphoblastic T-cell leukaemia and lymphoma: one or two diseases? Br J Haematol. 2010; 149(5):653-68.

13. Reiter A, Schrappe M, Ludwig WD, Tiemann M, Parwaresch R, Zimmermann $\mathrm{M}$, et al. Intensive ALL-type therapy without local radiotherapy provides a $90 \%$ event-free survival for children with T-cell lymphoblastic lymphoma: a BFM group report. Blood. 2000; 95(2):416-21.

14. Anderso JR, Jenkin RD, Wilson JF, Kjeldsberg CR, Sposto R, Chilcote RR, et al. Long-term follow-up of patients treated with COMP or LSA2L2 therapy for childhood non-Hodgkin's lymphoma: a report of CCG-551 from the Children's Cancer Group. J Clin Oncol. 1993; 11(6):1024-32.

15. Neth O, Seidemann K, Jansen P, Mann G, Tiemann M, Ludwig WD, et al Precursor B-cell lymphoblastic lymphoma in childhood and adolescence: clinical features, treatment, and results in trials NHL-BFM 86 and 90. Med Pediatr Oncol. 2000; 35(1):20-7.

16. Termuhlen AM, Smith LM, Perkins SL, Lones M, Finlay JL, Weinstein H, et al. Disseminated lymphoblastic lymphoma in children and adolescents: results of the COG A5971 trial: a report from the Children's Oncology Group. Br J Haematol. 2013; 162(6):792-801.

17. Swerdlow SH, Campo E, Harris NL, Jaffe E, Pieleri SA, Stein H (eds.). WHO classification of tumors of haematopoietic and lymphoide tissues. IARC WHO Classification of tumors. 2.ed. Lyon: IARC, 2008.

18. Murphy SB. Classification, staging and end results of treatment of childhood non- Hodgkin's lymphomas: dissimilarities from lymphomas in adults. Semin Oncol. 1980; 7(3):332-9.

19. Wollner N, Wachtel AE, Exelby PR, Centore D. Improved prognosis in children with intra-abdominal non-Hodgkin's lymphoma following LSA2L2 protocol chemotherapy. Cancer. 1980; 45(12):3034-9.

20. Reiter A, Schrappe M, Ludwig WD, Lampert F, Harbott J, Henze G, et al. Favorable outcome of B-cell acute lymphoblastic leukemia in childhood: a report of three consecutive studies of the BFM group. Blood. 1992; 80(10):2471-8.
21. Ducassou S, Ferlay C, Bergeron C, Girard S, Laureys G, Pacquement H, et al. Clinical presentation, evolution, and prognosis of precursor B-cell lymphoblastic lymphoma in trials LMT96, EORTC 58881, and EORTC 58951. Br J Haematol. 2011; 152(4):441-51.

22. Cunha KC, Oliveira MC, Gomes AC, de Castro LP, Viana MB. Clinical course and prognostic factors of children with Burkitt's lymphoma in a developing country: the experience of a single centre in Brazil. Rev Bras Hematol Hemoter 2012; 34(5):361-6

23. Gualco G, Klumb CE, Barber GN, Weiss LM, Bacchi CE. Pediatric lymphomas in Brazil. Clinics. 2010; 65(12):1267-77.

24. Burkhardt B, Zimmermann M, Oschlies I, Niggli F, Mann G, Parwaresch R, et al. The impact of age and gender on biology, clinical features and treatment outcome of non-Hodgkin lymphoma in childhood and adolescence. Br J Haematol. 2005; 131(1):39-49.

25. Sheibani K, Nathwani BN, Winberg CD, Burke JS, Swartz WG, Blayney D, et al. Antigenically defined subgroups of lymphoblastic lymphoma. Relationship to clinical presentation and biologic behavior. Cancer. 1987; 60(2):183-90.

26. Bonn BR, Rohde M, Zimmermann M, Krieger D, Oschlies I, Niggli F, et al. Incidence and prognostic relevance of genetic variations in T-cell lymphoblastic lymphoma in childhood and adolescence. Blood. 2013; 121(16):3153-60.

27. El-Mallawany NK, Frazer JK, Van Vlierberghe P, Ferrando AA, Perkins S, Lim $\mathrm{M}$, et al. Pediatric T- and NK-cell lymphomas: new biologic insights and treatment strategies. Blood Cancer J. 2012; 2(4):e65.

28. Abromowitch M, Sposto R, Perkins S, Zwick D, Siegel S, Finlay J, et al. Shortened intensified multi-agent chemotherapy and non-cross resistant maintenance therapy for advanced lymphoblastic lymphoma in children and adolescents: report from the Children's Oncology Group. Br J Haematol. 2008; 143(2):261-7.

29. Salzburg J, Burkhardt B, Zimmermann M, Wachowski O, Woessmann W, Oschlies I, et al. Prevalence, clinical pattern, and outcome of CNS involvement in childhood and adolescent non-Hodgkin's lymphoma differ by nonHodgkin's lymphoma subtype: a Berlin-Frankfurt-Munster Group Report. J Clin Oncol. 2007; 25(25):3915-22.

30. Coustan-Smith E, Sandlund JT, Perkins SL, Chen H, Chang M, Abromowitch $\mathrm{M}$, et al. Minimal disseminated disease in childhood T-cell lymphoblastic lymphoma: a report from the Children's Oncology Group. J Clin Oncol. 2009; 27(21):3533-9.

31. Lones MA, Heerema NA, Le Beau MM, Sposto R, Perkins SL, Kadin ME, et al. Chromosome abnormalities in advanced stage lymphoblastic lymphoma of children and adolescents: a report from CCG-E08. Cancer Genet Cytogenet 2007; 172(1):1-11.

32. Reiter A. Diagnosis and treatment of childhood non-Hodgkin lymphoma. Hematology Am Soc Hematol Educ Program. 2007:285-96. 